\title{
Incompatibility of sulphate compounds and soluble bicarbonate salts in the Rio Cruces waters: an answer to the disappearance of Egeria densa and black-necked swans in a RAMSAR sanctuary
}

\author{
Sandor Mulsow ${ }^{1,2, *}$, Mariano Grandjean ${ }^{1}$ \\ ${ }^{1}$ Instituto de Geociencias, and ${ }^{2}$ Forest Ecosystem Services Research (FORECOS), \\ Universidad Austral de Chile, Casilla 567-Valdivia, Chile
}

\begin{abstract}
The Carlos Anwandter Sanctuary, a RAMSAR site, is situated downstream from the junction of the Rio Cruces and Rio Calle-Calle near Valdivia in Southern Chile. The Rio Cruces was a bicarbonate-rich aquatic ecosystem until January 2004, when a pulp mill began pouring $>40 \mathrm{t}$ of sulphate $\left(\mathrm{SO}_{4}\right)$ and 6 to $9 \mathrm{t}$ of $\mathrm{H}_{2} \mathrm{SO}_{4}$ each day into the River. Soon after, black-necked swans, which take refuge in the Sanctuary, began to die and emigrate. Previous studies showed that the food of the birds, the submerged vascular plant Egeria densa, had been eliminated from areas of the Sanctuary affected by the mill's effluent. Here we describe the cause of this loss of plants and birds. E. densa is a $\mathrm{C}_{4}$ plant that uses calcium bicarbonate to compensate for low concentrations of $\mathrm{CO}_{2}$ in its local environment. Without calcium bicarbonate in the water, the plant photorespires, loses turgor, turns brown and dies. Here we demonstrate that the sulphate and acid dumped into the river by the pulp mill caused an anionic/cationic disequilibrium resulting in the precipitation of both $\mathrm{Mg}^{2+}$ and $\mathrm{Ca}^{2+}$ oxides - as brucite and portlandite - and other metallic $(\mathrm{Fe}, \mathrm{Al}, \mathrm{Cu})$ oxides which enhanced the concentration of $\mathrm{H}^{+}$, thus perpetuating the ionic disequilibrium. Further, aqueous sulphate under light acidic conditions could precipitate gypsum, thus further removing calcium from the water. An ecologically and statistically significant loss of calcium bicarbonate (ANOVA, $\mathrm{p}<0.05$ ) is shown: samples of water affected by the mill's effluent contained $37 \%$ less $\left(\mathrm{HCO}_{3}\right)^{-}$than those collected outside the area affected by the effluent. In a microcosm experiment, E. densa samples were exposed to no sulphate (4 replicates: control), $2.5 \mathrm{~g} \mathrm{l}^{-1}$ of $\mathrm{K}_{2} \mathrm{SO}_{4}$ (4 replicates: Treatment 1), $4.9 \mathrm{~g} \mathrm{l}^{-1}$ of $\mathrm{K}_{2} \mathrm{SO}_{4}$ (4 replicates: Treatment 2), and $9.8 \mathrm{~g} \mathrm{l}^{-1}$ of $\mathrm{K}_{2} \mathrm{SO}_{4}$ (4 replicates: Treatment 3). Plants in the control microcosms produced oxygen through photosynthesis at a rate of $0.24 \mathrm{ml} \mathrm{O}_{2} \mathrm{~g}^{-1} \mathrm{~h}^{-1}$. Plants in Treatment 1 produced oxygen at half the rate of the controls: $0.11 \mathrm{ml} \mathrm{O}_{2} \mathrm{~g}^{-1} \mathrm{~h}^{-1}$. Plants in Treatment 2 produced oxygen at a rate of $0.003 \mathrm{ml} \mathrm{O}_{2} \mathrm{~g}^{-1} \mathrm{~h}^{-1}$ or 2 orders of magnitude lower than plants in the control microcosms. After only $8 \mathrm{~h}$ of exposure to the experimental conditions of Treatment 3 , the plants produced oxygen at a rate of only $0.0001 \mathrm{ml} \mathrm{O}_{2} \mathrm{~g}^{-1} \mathrm{~h}^{-1}$ or 3 orders of magnitude lower than controls. Differences in oxygen production among the controls and treatments were statistically significant (ANOVA, $\mathrm{p}<0.05$ ).
\end{abstract}

KEY WORDS: Pulp mill $\cdot \mathrm{C}_{4} \cdot$ Photosynthesis $\cdot$ Egeria densa $\cdot$ Environmental disaster $\cdot \mathrm{CO}_{2}$ concentration mechanisms $\cdot \mathrm{CCM} \cdot$ Bicarbonate salts $\cdot$ Industrial pollution

Resale or republication not permitted without written consent of the publishe

\section{INTRODUCTION}

The Carlos Anwandter Sanctuary in Southern Chile is a RAMSAR site - an area of wetlands of international importance, designated as such under the United Nations Convention on Wetlands signed in Ramsar, Iran (UNESCO, 1971). The area is downstream from the junction of the Cruces and Rio Calle-Calle near Valdivia. The land formation was altered by the great 1960 earthquake and is now composed of slow moving streams, swamps and a tidal estuary that empties into the Pacific Ocean at the Bay and Port of Corral. The Sanctuary offers breeding grounds for a vast array of waterfowl. Eco-tourism is economically important to the area. The Sanctuary is now threatened by forestry plantations, agriculture, cattle husbandry, small and large urban waste water treatment facilities and, most recently, effluent from a 
new pulp mill. More than $90 \%$ of the waste water released into the Rio Cruces comes from the CELCOARAUCO pulp mill.

In January 2004, more than 6000 black-necked swans were counted in the Sanctuary. During April to May 2004, dozens of these swans were found dead, floating in the waters of the Sanctuary. After July, only a few hundred were left. By then, most of the blacknecked swans had emigrated from the Sanctuary and more than 200 swans had been found dead. The local authorities ordered an ecological assessment study to establish the cause of the disappearance and death of the birds. The local university, Universidad Austral de Chile (UACH), undertook exhaustive studies to define and eliminate hypotheses to explain the death of the birds (UACH 2004, 2005). The principal outcome of these studies was that the main food source for the birds, a vascular sub-aquatic plant, Egeria densa, had been completely eliminated from the Sanctuary. However, the studies did not identify the cause of the loss of E. densa. Here we report an experiment designed to determine why the plant disappeared.

Egeria densa and Elodea Canadensis, both occurred in the waters of the Sanctuary. They are $\mathrm{C}_{4}$ photosynthetic vascular plants, which are adapted to living in habitats with low concentrations of $\mathrm{CO}_{2}$; ribulose-1, 5-bisphosphate carboxylase/oxygenase (RuBisCo) catalyzes either photosynthesis or photorespiration, depending on the concentration of $\mathrm{CO}_{2}$ or $\mathrm{O}_{2}$ in their local environment (Browse et al. 1977, 1979, Bowes et al. 1978, Bowes \& Salvucci 1989, Long 1991, 1999, Magnin et al. 1996, 1997, Reiskind et al. 1997, Casati et al. 2000, Leegood 2002, Maberly \& Madsen 2002). Diffusion of $\mathrm{CO}_{2}$ in water is $10^{4}$ times lower than in air. Low $\mathrm{CO}_{2}$ concentrations and high concentrations of $\mathrm{O}_{2}$ in the water lead RuBisCo toward photorespiration and away from photosynthesis (Holaday \& Bowes 1980, Leegood 2002).

Submersed plants, algae and cyanobacteria among others, compensate for these adverse conditions through biophysical or proton extrusion mechanisms (together referred to as $\mathrm{CO}_{2}$ concentration mechanisms, CCM). These mechanisms convert soluble calciumbicarbonate $\left(\mathrm{HCO}_{3}\right)^{-}$to $\mathrm{CO}_{2}$. At least 3 species of Hydrocharitaceae - Hydrilla verticillata (Bowes et al. 1979, Holaday et al. 1983, Moore et al. 1987, Morton \& Keeley, 1990, Magnin et al. 1997), Egeria densa (Dai et al. 1993, Casati et al. 2000) and Elodea canadensis (de Groote \& Kennedy 1977) - show evidence of $\mathrm{C}_{4}$ metabolism associated with CCM (Bowes et al. 1971). Badger \& Spalding (2000) proposed a generic model to describe CCM in submersed plants, such as E. densa: the poor affinity of RuBisCo for $\mathrm{CO}_{2}$ and its relatively high affinity for $\mathrm{O}_{2}$ requires that the plants increase intracellular partial pressures of $\mathrm{CO}_{2}$ incorporating soluble salts of
$\left(\mathrm{HCO}_{3}\right)^{-}$present in the surrounding water, otherwise $E$. densa cannot photosynthesise (see Leegood 2002 for details). Calcium bicarbonate in water can be easily disassociated by a stronger anion such as $\mathrm{SO}_{4}{ }^{2-}$. It is also affected by $\mathrm{pH}<7.0$ and by high temperatures.

In January 2006, CELCO-ARAUCO began operation of a kraft-bleached type pulp mill on the Rio Cruces above the RAMSAR Sanctuary. The mill has an annual capacity limited to $550000 \mathrm{t}$ (WWF 2005). It discharges $\mathrm{SO}_{4}$ into the river at a rate of $>40 \mathrm{t} \mathrm{d}^{-1}$ (the pulp mill stated officially that the discharge of sulphate is in the order of $40 \mathrm{t} \mathrm{d}^{-1}$, but they have been fined for operating in excess of this limit). Aluminum sulphate, similar to ALUM ${ }^{\mathrm{TM}}$, a hydrated salt of aluminum, coagulates suspended material $\left(\mathrm{Al}^{3+}\right)$ and clarifies the effluent before it leaves the mill. The plant also reports the discharge of 6 to $9 \mathrm{t} \mathrm{d}^{-1}$ of $\mathrm{H}_{2} \mathrm{SO}_{4}$.

Before the pulp mill began operations, (1) Campos (1995) characterized the Rio Cruces as a freshwater river buffered with bicarbonate concentrations of 27.9 $\pm 8.7(\mathrm{SD}) \mathrm{mg}\left(\mathrm{HCO}_{3}\right)^{-} \mathrm{l}^{-1}(\mathrm{n}=7)$ and (2) water at a sampling station (named Puente Rucaco) located $1 \mathrm{~km}$ downstream of the pulp mill had concentrations of $\mathrm{SO}_{4}$ $<0.6 \pm 0.3(\mathrm{SD}) \mathrm{mg} \mathrm{SO} \mathrm{l}^{-1}(\mathrm{n}=20)$ (DGA 1993). In February 2006 at the same station, we measured concentrations of $\mathrm{SO}_{4}$ as high as $4.5 \mathrm{mg} \mathrm{l}^{-1}$ - more than 7 times its historic levels.

\section{MATERIALS AND METHODS}

In February-March 2006, 2 yr after the pulp mill began production, we sampled 11 stations along the Rio Cruces. Two stations were located upstream of the effluent discharge (Table 1), 1 station was $1 \mathrm{~km}$ downstream of the effluent discharge (Puente Rucaco, Table 1), 6 stations were located within the limit of the Sanctuary and 2 were located in the Rio Calle-Calle. The samples were collected using a van Dorn bottle from a research vessel at the stations located in the Sanctuary and Rio Calle-Calle and by hand using SCUBA equipment at stations located upstream and downstream of the pulp mill.

Concentrations of $\mathrm{CO}_{2}$ and $\left(\mathrm{HCO}_{3}\right)^{-}$were analyzed on site using titration techniques (Parson et al. 1985), and $\mathrm{pH}$ was measured using an Orion temperature corrected $\mathrm{pH}$ meter. Water samples for analysis of major cations and anions were collected using a highdensity plastic bottle and kept cool before being sent to SERNAGEOMIN, an ISO 9000 credited Laboratory, for analysis. Cations and anions were determined using Ionic DX Chromatography. The cation/anion concentration values were then entered into WATEQ4F (Ball $\&$ Nordstrom 2001) to evaluate the cation/anion equilibrium. 
Table 1. Bicarbonate concentrations measured in the water column. Values are means \pm SD of 6 replicates from 11 stations located upstream and downstream of the pulp mill effluent. Shaded rows represent stations located within the limits of the Carlos Anwandter Sanctuary that have been heavily impacted by the effluent.

\begin{tabular}{|c|c|c|c|c|c|}
\hline Stn & $\begin{array}{l}\text { Latitude } \\
\quad\left({ }^{\circ} \mathrm{S}\right)\end{array}$ & $\begin{array}{l}\text { Longitude } \\
\left({ }^{\circ} \mathrm{W}\right)\end{array}$ & $\begin{array}{l}\text { Depth } \\
\text { (m) }\end{array}$ & $\begin{array}{c}\mathrm{SO}_{4} \\
\left(\mathrm{mg} \mathrm{l}^{-1}\right)\end{array}$ & $\begin{array}{c}\text { Alkalinity } \\
\left(\mathrm{mg} \mathrm{HCO}_{3} \mathrm{l}^{-1}\right)\end{array}$ \\
\hline Puente Cruces & $39^{\circ} 26^{\prime} 9.9$ & $72^{\circ} 45^{\prime} 35.9$ & 1 & 0.70 & $29.48 \pm 1.76$ \\
\hline Puente Negro & $39^{\circ} 29^{\prime} 21.6$ & $72^{\circ} 48^{\prime} 33.8$ & 1 & 0.77 & $35.07 \pm 10.78$ \\
\hline Puente Rucaco ${ }^{\mathrm{a}}$ & $39^{\circ} 33^{\prime} 6.6$ & $72^{\circ} 54^{\prime} 8.0$ & 1 & 4.52 & $24.40 \pm 3.05$ \\
\hline \multirow[t]{2}{*}{ Isla Teja } & $39^{\circ} 47^{\prime} 15.0$ & $73^{\circ} 16^{\prime} 31.3$ & 0 & 3.37 & $20.33 \pm 1.76$ \\
\hline & & & 5 & 3.39 & $28.46 \pm 1.76$ \\
\hline \multirow[t]{2}{*}{ Cabo Blanco } & $39^{\circ} 46^{\prime} 39.4$ & $73^{\circ} 15^{\prime} 21.3$ & 0 & 3.32 & $19.31 \pm 1.76$ \\
\hline & & & 3 & 3.40 & $17.28 \pm 1.76$ \\
\hline \multirow[t]{2}{*}{ Punucapa } & $39^{\circ} 45^{\prime} 26.3$ & $73^{\circ} 15^{\prime} 39.5$ & 0 & 3.32 & $16.26 \pm 1.76$ \\
\hline & & & 6 & 3.23 & $14.23 \pm 1.76$ \\
\hline \multirow[t]{2}{*}{ San Ramón } & $39^{\circ} 44^{\prime} 14.0$ & $73^{\circ} 16^{\prime} 4.4$ & 0 & 2.84 & $15.25 \pm 0.00$ \\
\hline & & & 2 & 2.82 & $14.23 \pm 1.76$ \\
\hline \multirow[t]{2}{*}{ Tres Bocas } & $39^{\circ} 43^{\prime} 34.9$ & $73^{\circ} 14^{\prime} 53.6$ & 0 & 3.17 & $16.26 \pm 1.76$ \\
\hline & & & 3 & 3.12 & $19.31 \pm 1.76$ \\
\hline \multirow[t]{2}{*}{ Cau Cau } & $39^{\circ} 47^{\prime} 5.1$ & $73^{\circ} 15^{\prime} 53.0$ & 0 & 1.88 & $21.35 \pm 3.05$ \\
\hline & & & 6 & 2.58 & $21.35 \pm 0.00$ \\
\hline \multirow[t]{2}{*}{ Calle-Calle 1} & $39^{\circ} 48^{\prime} 53$ & $73^{\circ} 14^{\prime} 1.5$ & 0 & 1.37 & $26.43 \pm 1.76$ \\
\hline & & & 4 & 1.36 & $29.48 \pm 1.76$ \\
\hline \multirow[t]{2}{*}{ Calle-Calle $2^{\mathrm{b}}$} & $39^{\circ} 49^{\prime} 12.4$ & $73^{\circ} 13^{\prime} 23.6$ & 0 & 1.26 & $29.48 \pm 1.76$ \\
\hline & & & 5 & 1.34 & $32.53 \pm 4.65$ \\
\hline \multicolumn{6}{|c|}{$\begin{array}{l}{ }^{\text {a }} \text { Puente Rucaco station is located } 1 \text { to } 2 \mathrm{~km} \text { downstream of effluent discharge } \\
\text { and has the highest value of sulphate recorded and reported here } \\
{ }^{\mathrm{b}} \text { At this staion water and plants were collected for the experimental work }\end{array}$} \\
\hline
\end{tabular}

cates or to one of 4 replicates of 3 different treatments. The 4 control replicates had no addition of $\mathrm{K}_{2} \mathrm{SO}_{4}$. The 4 replicates of Treatment 1 received a dose equivalent to $15 \mathrm{~d}$ of sulphate released by the pulp mill (specific concentration of $2.5 \mathrm{~g} \mathrm{SO}_{4}$ $\mathrm{l}^{-1}$ ). The 4 replicates of Treatment 2 received the equivalent of $30 \mathrm{~d}$ of sulphate release (specific concentration of $4.9 \mathrm{~g} \mathrm{SO}_{4} \mathrm{l}^{-1}$ ) and the 4 replicates of Treatment 3 received the equivalent of $60 \mathrm{~d}$ of sulphate effluent (specific concentration of $9.8 \mathrm{~g}$ $\mathrm{SO}_{4} \mathrm{l}^{-1}$ ).

Calculation of the equivalent doses was based on the company's own estimate of $40 \mathrm{t} \mathrm{d}^{-1}$ of sulphate release by the pulp mill — an estimate lower than that provided by UACH (2005) which, in December 2004, stated that CELCO-ARAUCO discharged $59 \mathrm{t} \mathrm{d}^{-1}$ of sulphate salts. We then used a dilution factor for the Sanctuary of $250 \times 10^{6} 1$ to arrive at $15 \mathrm{~d}\left(2.5 \mathrm{~g} \mathrm{SO}_{4} \mathrm{l}^{-1}\right), 30 \mathrm{~d}\left(4.5 \mathrm{~g} \mathrm{SO}_{4}\right.$ $\mathrm{l}^{-1}$ ) and $60 \mathrm{~d}\left(9.8 \mathrm{~g} \mathrm{SO}_{4} \mathrm{l}^{-1}\right)$ equivalent doses of sulphate in the treat-

For experiments, complete and healthy Egeria densa plants as well as water were collected from Stn CalleCalle 2 (see Table 1); these samples were considered unaffected by the pulp mill effluent. Water and plants were transported immediately in a cooler to the Geobenthos Laboratory at UACH. Once in the Laboratory, four $100 \mathrm{l}$ glass aquaria were filled with tap water and kept at 14 to $16^{\circ} \mathrm{C}$ with a custom made chilling device. In each aquarium, four $10 \mathrm{l}$ glass microcosms were arranged, aerated and kept out of contact with the refrigerated water. In each of these, we placed a section of $E$. densa stem with verticillata in good condition and including the apex $(0.6$ to $0.8 \mathrm{~g}$ dry wt) inside an inverted, transparent gas-tight funnel (bio-oxygen meter). At the tip of the funnel, a plastic syringe was inserted and filled with water. Oxygen produced by the plant rose into the tip of the funnel displacing water. Oxygen production was used to estimate the photosynthesis rate of the plant $\left(\mathrm{ml} \mathrm{O} \mathrm{g}^{-1} \mathrm{~h}^{-1}\right)$.

To test the effects of sulphate effluent on the plants, all 101 microcosms described above were fitted with a bio-oxygen meter and a sample of Egeria densa and allowed to produce oxygen for $8 \mathrm{~h}$. In this way, the natural photosynthetic rate was determined for each plant. Then, 4 individual plant samples (replicates) were designated randomly to one of 4 control repli- ment microcosms. Statististical analyses were carried out using a PC program Statistica ${ }^{\mathrm{TM}}$. Differences were considered significant at $\mathrm{p}<0.05$.

\section{RESULTS}

\section{Fieldwork}

The concentration of $\left(\mathrm{HCO}_{3}\right)^{-}$was statistically significantly higher at stations located outside the Sanctuary and outside the areas affected by pulp mill effluent than that at stations located within the Sanctuary boundaries downstream of the pulp mill effluent, including Puente Rucaco (1-way ANOVA, p < 0.005). In general, the samples outside the affected parts of the Sanctuary had up to $37 \%$ more $\left(\mathrm{HCO}_{3}\right)^{-}$than those collected inside the area affected by the pulp mill effluent (Table 1).

The concentration of $\mathrm{SO}_{4}$ was 3 times higher at Rucaco and at stations within the Sanctuary than that at stations located outside the areas influenced by the pulp mill; these differences are ecologically and statistically significant (1-way ANOVA, p < 0.05) (Table 1).

There was a strong negative correlation $\left(\mathrm{r}^{2}=0.81 ; \mathrm{p}<\right.$ 0.05 ) between the concentration of $\mathrm{SO}_{4}$ and $\mathrm{HCO}_{3}$ i thus, the higher the concentration of sulphate, the lower the 
concentration of $\mathrm{HCO}_{3}$. Furthermore, in the period 1987 to 1992, Puente Rucaco station had $\mathrm{SO}_{4}$ concentrations 5 times lower than those observed today $(0.6 \pm 0.3 \mathrm{mg}$ $\mathrm{SO}_{4} \mathrm{l}^{-1}, \mathrm{n}=20$; Rio Rucaco: 1987 to 1992; DGA 1993).

All $\mathrm{pH}$, temperature and cation and anion concentrations $\left(\mathrm{HCO}_{3}{ }^{2-}, \mathrm{SO}_{4}{ }^{2-}, \mathrm{Cl}^{-}, \mathrm{NO}_{3}{ }^{-}, \mathrm{Ca}^{2+}, \mathrm{Mg}^{2+}, \mathrm{Na}^{+}\right.$ and $\mathrm{K}^{+}$) measured for the 11 sample stations were analyzed using WATEQ4F (Ball \& Nordstrom, 2001) to examine the tendency of water to reach mineral solubility equilibria as a constraint on interpreting the chemistry of natural waters (Ball \& Norstrom, 2001). The calculated differences in cation/anion balance between stations affected by the pulp mill effluent and those unaffected were ecologically and statistically significant (ANOVA, p < 0.05). When we compared our data with the historical data collected by the Direccion General de Aguas de Chile (DGA) during 1987 to 1992, sites unaffected by the effluent today were not statistically different from the historical data, while sites downstream from the pulp mill effluent today were.

The chemical changes outlined above coupled with rises in temperature and decreases in $\mathrm{pH}$ has induced the formation of fulvic-humic complexes-yellow substance or Gelbstoff - that now colors and clouds the waters of the Sanctuary. The presence of anions increased conductivity dramatically to levels higher than $6000 \mu \mathrm{S} \mathrm{cm}^{-2}$ (S. Mulsow pers. obs.).

Egeria densa was only found in waters with $\left(\mathrm{HCO}_{3}\right)^{-}$ concentrations greater than $26 \mathrm{mg}\left(\mathrm{HCO}_{3}\right)^{-} \mathrm{l}^{-1}$ and geographically was only found in the waters of the Rio Calle-Calle that were unaffected by the pulp mill effluent. E. densa was not found when the water concentration of $\left(\mathrm{HCO}_{3}\right)^{-}$was less than $20 \mathrm{mg}\left(\mathrm{HCO}_{3}\right)^{-} \mathrm{l}^{-1}$ or $\mathrm{SO}_{4}{ }^{2-}$ concentration was higher than $1.8 \mathrm{mg} \mathrm{\textrm {SO } _ { 4 }}{ }^{2-}$ $\mathrm{l}^{-1}$. $\mathrm{SO}_{4}{ }^{2-}$ was the only major chemical compound that the pulp mill was known to release that was not subject to an environmental impact study prior to the mill's operation.

Analysis with WATEQ4F showed that the waters affected by the pulp mill's effluent including those in the Sanctuary were supersaturated with the mineral phases of brucite and portlandite-both $\mathrm{Mg}^{+2}$ and $\mathrm{Ca}^{+2}$ oxides. Aqueous sulphate under light acidic conditions can precipitate gypsum $\left(\mathrm{CaSO}_{4} \cdot 2 \mathrm{H}_{2} \mathrm{O}\right)$, thus further removing calcium from the water. The calcium comes only from the mineral phases of soils in the watershed. Thus, the source of calcium is limited. Removal of calcium through mineral formation lowers the concentration of calcium bicarbonate. Further, the over abundance of anions in the waters affected by the pulp mill effluent coupled with high concentrations of aluminum (UACH 2005) causes loss of dissolved cations. In addition to the formation of brucite and portlandite, other metallic $(\mathrm{Fe}, \mathrm{Al}, \mathrm{Cu})$ oxides can form which enhances the concentration of $\mathrm{H}^{+}$thus perpetuating the cation/anion disequilibrium.

In the spring and summer, the temperature of the waters in the Sanctuary rises. Even an increase in temperature of a few tenths of a degree $\left({ }^{\circ} \mathrm{C}\right)$ would further increase the imbalance of the $\mathrm{CaCO}_{3}-\mathrm{HCO}_{3}-$ $\mathrm{CO}_{2}-\mathrm{H}_{2} \mathrm{O}$ buffer system. The buffering system of water in the Sanctuary, which was at equilibrium before the pulp mill began operations, rapidly collapsed creating buffer deficiencies in the Rio Cruces.

Furthermore, the waters in the estuary of Rio Cruces are slow moving-residence time is long. Thus the reaction time of chemical compounds released into the river, such as $\mathrm{SO}_{4}$, is extended, exacerbating the effects of the added material on the ecosystem. The result is the direct and negative effect on Egeria densa and the indirect and negative effect on the blacknecked swan for which the Sanctuary was a refuge.

\section{Experimental work}

The rates of photosynthetic production of oxygen in the initial experiment in all microcosms - those used as controls or treatment vessels - were not statistically different (Fig. 1, no addition of sulphate; ANCOVA, p < 0.05). However when the same plants, were exposed to a dose of $\mathrm{SO}_{4}$ salt equivalent to $15 \mathrm{~d}\left(2.5 \mathrm{~g} \mathrm{SO}_{4} \mathrm{l}^{-1}\right), 30 \mathrm{~d}$ $\left(4.9 \mathrm{~g} \mathrm{SO}_{4} \mathrm{l}^{-1}\right)$ and $60 \mathrm{~d}\left(9.8 \mathrm{~g} \mathrm{SO}_{4} \mathrm{l}^{-1}\right)$, photosynthetic rates decreased by orders of magnitudes compared to controls, and the differences were statistically significant (Fig. 2). Controls produced oxygen at a rate of $0.24 \mathrm{ml} \mathrm{O}_{2}$ $\mathrm{g}^{-1} \mathrm{~h}^{-1}$. Plants in Treatment $1\left(2.5 \mathrm{~g} \mathrm{SO}_{4} \mathrm{l}^{-1}\right)$ produced oxygen at half the rate of the controls: $0.11 \mathrm{ml} \mathrm{O}_{2} \mathrm{~g}^{-1} \mathrm{~h}^{-1}$. Plants in Treatment $2\left(4.9 \mathrm{~g} \mathrm{SO}_{4} \mathrm{l}^{-1}\right)$ produced oxygen at a rate 2 orders of magnitude lower than plants in the control microcosm: $0.003 \mathrm{ml} \mathrm{O}_{2} \mathrm{~g}^{-1} \mathrm{~h}^{-1}$. After only $8 \mathrm{~h}$ of exposure to the experimental conditions of Treatment 3 $\left(9.8 \mathrm{~g} \mathrm{SO}_{4} \mathrm{l}^{-1}\right)$, the plants produced oxygen at a rate 3 orders of magnitude lower than those in the control microcosm: $0.0001 \mathrm{ml} \mathrm{O}_{2} \mathrm{~g}^{-1} \mathrm{~h}^{-1}$.

The only compound added to the treatment microcosms was $\mathrm{SO}_{4}$ in the form of $\mathrm{K}_{2} \mathrm{SO}_{4}$ (Merck grade). The initial conditions $\left(\mathrm{pH}, \mathrm{CO}_{2}\right.$, temperature, $\mathrm{HCO}_{3}{ }^{-}$) of the water in the controls did not change during the experiment. However, these variables changed in the treatment microcosms. A change in $\mathrm{pH}$ of 0.4 over the course of the experiment (Table 2) that indicates an ecologically significant decrease in the concentration of $\left(\mathrm{HCO}_{3}\right)^{-}$had occurred. In all the treatments, $\left(\mathrm{HCO}_{3}\right)^{-}$decreased 10 to $30 \%$ compared to initial concentrations and, in these microcosms, Egeria densa decreased its photosynthetic rate by orders of magnitude (Table 2). The plants lost rigidity and turned brown; their health deteriorated. 


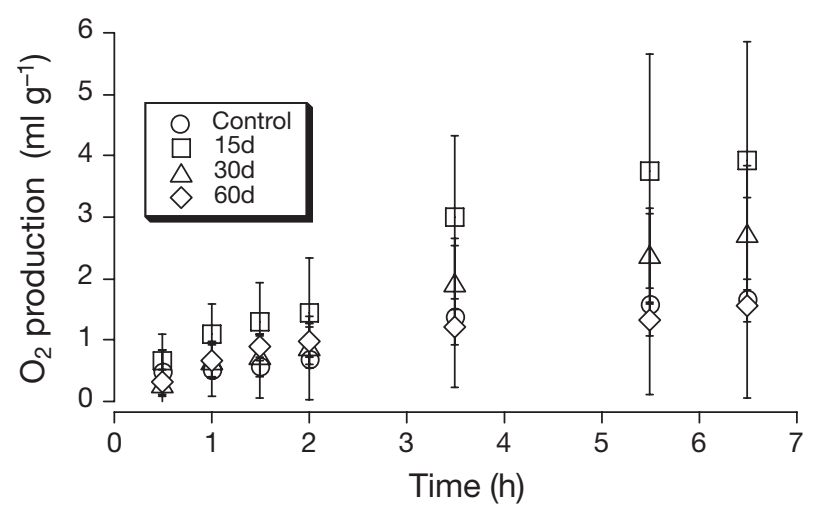

Fig. 1. Egeria densa. Initial photosynthetic rate determined as oxygen production before the plants were exposed to sulphate salt. $15 \mathrm{~d}\left(2.5 \mathrm{~g} \mathrm{~K}_{2} \mathrm{SO}_{4} \mathrm{l}^{-1}\right)$, $30 \mathrm{~d}\left(4.9 \mathrm{~g} \mathrm{~K}_{2} \mathrm{SO}_{4} \mathrm{l}^{-1}\right)$ and $60 \mathrm{~d}\left(9.8 \mathrm{~g} \mathrm{~K}_{2} \mathrm{SO}_{4} \mathrm{l}^{-1}\right)$ exposure equivalent doses were administered in separate microcosms after this initial trial

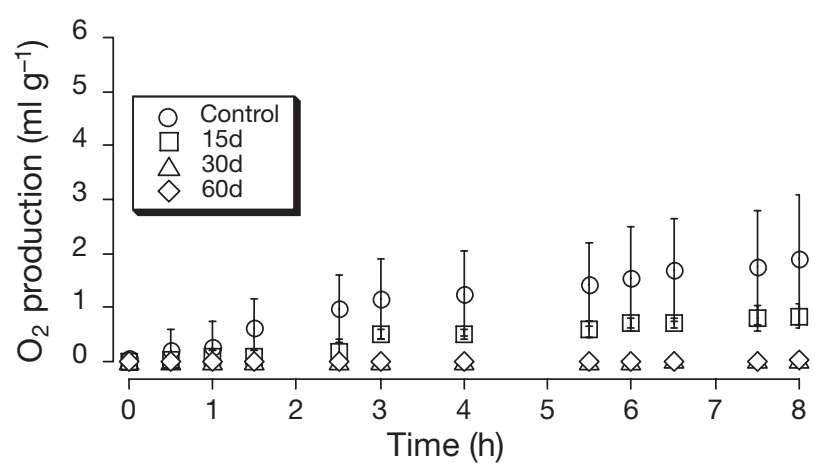

Fig. 2. Egeria densa. Photosynthetic rate determined as oxygen production after the plants were exposed to sulphate salt. The control plants produced more than $1 \mathrm{ml}$ of oxygen per hour per gram of plant. Plants exposed to $15 \mathrm{~d}$ equivalent dose $\left(2.5 \mathrm{~g} \mathrm{~K}_{2} \mathrm{SO}_{4} \mathrm{l}^{-1}\right)$ produced less than $50 \%$ of the control, those plants exposed to $30 \mathrm{~d}\left(4.9 \mathrm{~g} \mathrm{~K}_{2} \mathrm{SO}_{4} \mathrm{l}^{-1}\right)$ and $60 \mathrm{~d}\left(9.8 \mathrm{~g} \mathrm{~K}_{2} \mathrm{SO}_{4}\right.$ $\mathrm{l}^{-1}$ ) equivalent doses produced oxygen at a rate 2 and 3 orders of magnitude lower than that of the control. At the end of the experiment, the plants exposed to the 2 highest doses of sulphate did not produce more oxygen after $4 \mathrm{~h}$ of exposure, i.e. no photosynthesis

\section{DISCUSSION}

We have demonstrated that the addition of $\mathrm{SO}_{4}$ decreased the concentration of $\left(\mathrm{HCO}_{3}\right)^{-}$in the experimental microcosms. The concentration of $\mathrm{CO}_{2}$ was similar before and after the experiment. Egeria densa, a $\mathrm{C}_{4}$ vascular plant that uses $\left(\mathrm{HCO}_{3}\right)^{-}$salt uptake as a $\mathrm{CO}_{2}$ concentrating mechanism could not photosynthesize (generate oxygen) when exposed to low concentrations of $\mathrm{SO}_{4}$.

A similar phenomenon must have occurred in the Sanctuary after the CELCO-ARAUCO pulp mill began operations in January-February 2004 (Table 1).
Table 2. Microcosm experimental conditions for Egeria densa before and after addition of $\mathrm{K}_{2} \mathrm{SO}_{4}$. Water and plants were collected at Stn Calle-Calle 1, outside the affected Sanctuary

\begin{tabular}{|lcccc|}
\hline & $\mathrm{pH}$ & $\begin{array}{c}\mathrm{Temp} . \\
\left({ }^{\circ} \mathrm{C}\right)\end{array}$ & $\begin{array}{c}\mathrm{CO}_{2} \\
\left(\mathrm{mg} \mathrm{l}^{-1}\right)\end{array}$ & $\begin{array}{c}\mathrm{HCO}_{3} \\
\left(\mathrm{mg} \mathrm{l}^{-1}\right)\end{array}$ \\
\hline $\begin{array}{l}\text { Initial conditions } \\
\text { Control }\end{array}$ & 7.8 & 15.0 & $1.95 \pm 0.47$ & $25.9 \pm 2.8$ \\
Treatment 1 & 7.9 & 14.5 & $1.47 \pm 0.25$ & $30.5 \pm 1.1$ \\
Treatment 2 & 7.8 & 14.5 & $1.76 \pm 0.44$ & $31.5 \pm 1.7$ \\
Treatment 3 & 7.7 & 15.0 & $1.70 \pm 0.54$ & $27.8 \pm 2.6$ \\
Final conditions & & & & \\
Control & 7.7 & 15.0 & $1.87 \pm 0.46$ & $25.3 \pm 2.7$ \\
Treatment 1 & 7.4 & 15.5 & $1.76 \pm 0.44$ & $26.4 \pm 3.5$ \\
Treatment 2 & 7.3 & 16.0 & $1.46 \pm 0.25$ & $24.4 \pm 3.1$ \\
Treatment 3 & 7.3 & 14.8 & $1.65 \pm 0.61$ & $22.6 \pm 2.1$ \\
& & & & \\
\hline
\end{tabular}

As a consequence of the mills discharge of $\mathrm{SO}_{4}$, concentrations of this toxin rose 5 to 6 times in the Rio Cruces and 3 to 4 times in the waters of the Sanctuary downstream. Calcium bicarbonate decreased 1.6 times in the same waters. When a similar decrease occurred in our experiment, the plants responded by reducing photosynthesis and they lost their rigidity and turned brown. Their health deteriorated.

Egeria densa is a $\mathrm{C}_{4}$ vascular submersed plant that uses calcium bicarbonate to concentrate $\mathrm{CO}_{2}$ near its RuBisCo enzyme to enhance the enzyme's photosynthetic capacity in conditions of low $\mathrm{CO}_{2}$ and high $\mathrm{O}_{2}$ concentrations (Bowes et al. 1971, 1979, Leegood et al. 2002). When the plant is confronted with low calcium bicarbonate concentrations and resulting low $\mathrm{CO}_{2}$, and high $\mathrm{O}_{2}$, RuBisCo is unable to catalyze photosynthesis and begins to catalyze photorespiration instead.

All previous studies of the ecological disaster in the Carlos Anwandter Sanctuary following the onset of operations at the CELCO-ARAUCO pulp mill were observational and presented correlations only, not cause and effect relationships (UACH 2004, 2005). These studies observed that only submersed vascular plants died off after the mill opened and only in areas affected by the mill's effluent. The plants lost turgor, displayed deposits on their surfaces, turned brown and died (UACH 2004, 2005). The submerged vascular plant Egeria densa is the major source of food for the black-necked swans that take refuge in the Sanctuary. When this plant died as a result of the $\mathrm{SO}_{4}$ released by the mill, as demonstrated here, the birds died or emigrate from the Sanctuary. The birds, like the plants in the treatment microcosms, showed signs of low resilience to environmental stresses that they had previously survived, displayed enhanced colonization by parasites and exhibited low rates of depuration of metals (UACH 2004, 2005). The health of the birds 
deteriorated, just as the health of the plants had deteriorated in the treatment microcosms.

The present study demonstrates that $\mathrm{SO}_{4}$ salts released by the CELCO-ARAUCO pulp mill forced the $\mathrm{CO}_{2} / \mathrm{HCO}_{3} / \mathrm{CO}_{3}$ equilibrium towards an ecologically and statistically significant decrease in $\left(\mathrm{HCO}_{3}\right)^{-}$, a compound essential to Egeria densa's photosynthetic production, health and survival.

We have reproduced the significant inverse relation of $\mathrm{SO}_{4}$ concentration and $\left(\mathrm{HCO}_{3}\right)^{-}$found in the 11 stations sampled. The presence of strong acids in the aquatic system disrupted the following equilibrium:

$$
\begin{gathered}
2\left[\mathrm{Ca}^{2+}\right]+2\left[\mathrm{Mg}^{2+}\right]+\left[\mathrm{Na}^{+}\right]+\left[\mathrm{K}^{+}\right]+\left[\mathrm{H}^{+}\right] \Leftrightarrow 2\left[\mathrm{CO}_{3}{ }^{2-}\right] \\
+\left[\mathrm{HCO}_{3}^{-}\right]+\left[\mathrm{Cl}^{-}\right]+2\left[\mathrm{SO}_{4}{ }^{2-}\right]+\left[\mathrm{OH}^{-}\right]+\left[\mathrm{NO}_{3}^{-}\right]
\end{gathered}
$$

After losing the ionic equilibrium, addition of $\mathrm{SO}_{4}{ }^{2-}$ resulted in the loss of $\left(\mathrm{HCO}_{3}\right)^{-}$according to:

$$
\mathrm{H}_{2} \mathrm{SO}_{4}+\mathrm{Ca}\left(\mathrm{HCO}_{3}\right) \Leftrightarrow \mathrm{CaSO}_{4}+2 \mathrm{CO}_{2}+\mathrm{H}_{2} \mathrm{O}
$$

Thus, a strong negative correlation results between $\mathrm{SO}_{4}$ and $\left(\mathrm{HCO}_{3}\right)^{-}$as demonstrated here. At near neutral $\mathrm{pH}$, this relationship can be summarized as:

$$
\left[\mathrm{HCO}_{3}\right]^{-} \Leftrightarrow 2\left[\mathrm{Ca}^{2+}+\mathrm{Mg}^{2+}\right]-2\left[\mathrm{SO}_{4}{ }^{2-}\right]
$$

The fact that the waters affected by the pulp mill effluent are supersaturated with calcium and magnesium oxides confirms the argument that $\mathrm{SO}_{4}{ }^{2-}$ has been the main cause of the ionic disequilibrium that resulted in the loss of the calcium bicarbonate in the water and the loss of the source of $\mathrm{CO}_{2}$ needed by Egeria densa to photosynthesise.

The chemical equations above can also be affected by increases in temperature and slight decreases in $\mathrm{pH}$. In both cases, since $\mathrm{CO}_{2}$ is at equilibrium with $\mathrm{H}_{2} \mathrm{CO}_{3}$, escape of $\mathrm{CO}_{2}$ results in decreased concentrations of $\left(\mathrm{HCO}_{3}\right)^{-}$because bicarbonate is a semi-soluble weak salt in natural waters.

It is precisely this partially dissolved salt of calcium bicarbonate that Egeria densa needs for photosynthesis (Prins et al. 1982, Salvucci \& Bowes 1983, SandJensen et al. 1985, Gordon 1986) allowing the plants to grow and multiply, thus providing food to sustain the populations of black-necked swans. This calcium bicarbonate has been removed by addition of sulphate, seasonally elevated temperatures and slight acidification of the water.

Acknowledgements. The authors thank the students of Geobenthos Laboratory for their constant help while sampling and during experimental work. Partial funding from FONDECYT (grant no. 1050247) to S.M. and analysis and logistics from FORECOS are acknowledged. To Cedric and Fabrice, Sandor Mulsow's sons, for their pristine environmen- tal concern and constant reminders throughout: What are you doing for the Sanctuary, Dad?

Disclosure: conflicts of interest. The authors have no personal, financial, political and/or other conflict of interest with the pulp mill or any other industries linked to the study area. The sole motivation of this research was to understand why an ecologically valuable submersed plant disappeared from the waters of the River Cruces and the Carlos Anwandter Sanctuary, a RAMSAR site.

\section{LITERATURE CITED}

Badger $\mathrm{MR}$, Spalding $\mathrm{MH}$ (2000) $\mathrm{CO}_{2}$ acquisition, concentration and fixation in cyanobacteria and algae. In: Leegood RC, Sharkey TD, Von Caemmerer S (eds) Photosynthesis: physiology and metabolism. Advances in photosynthesis, Vol 9. Kluwer Academic Publishers, Dordrecht, p 369-397

Ball JW, Nordstrom DK (2001) User's manual for WATEQ4F, with revised thermodynamic data base and test cases for calculating speciation of major, trace, and redox elements in natural waters: US Geological Survey Open-File Report 91-193, Menlo Park, CA

Bowes G, Salvucci ME (1989) Plasticity in the photosynthetic carbon metabolism of submersed aquatic macrophytes. Aquat Bot 34:233-266

Bowes G, Ogren WL, Hageman RH (1971) Phosphoglycolate production catalyzed by ribulose diphosphate carboxylase. Biochem Biophys Res Commun 45:716-722

Bowes G, Holaday AS, Van TK, Haller WT (1978) Photosynthetic and photorespiratory carbon metabolism in aquatic plants. In: Hall DO, Coombs J, Goodwin TM (eds) Photosynthesis '77. Proc Fourth Int Congr Photosynthesis. The Biogeochemical Society, London, p 289-298

Bowes G, Holaday AS, Haller WT (1979) Seasonal variation in the biomass, tuber density, and photosynthetic metabolism of Hydrilla in three Florida lakes. J Aquat Plant Manag 17:61-65.

Browse JA, Dromgoole FI, Brown JMA (1977) Photosynthesis in the aquatic macrophyte Egeria densa. I. ${ }^{14} \mathrm{CO}_{2}$ fixation at natural $\mathrm{CO}_{2}$ concentrations. Aust J Plant Physiol 4:169-176

Browse JA, Brown JMA, Dromgoole FI (1979) Photosynthesis in the aquatic macrophyte Egeria densa. II. Effects of inorganic carbon conditions on ${ }^{14} \mathrm{CO}_{2}$ fixation. Aust $\mathrm{J}$ Plant Physiol 6:1-9

Campos H (1995) Caracterización fisico química de las aguas del Rio Cruces. En: Estudio de impacto ambiental de CELCO-ARAUCO, por Arcadis Geotecnica. CONAMAChile

Casati P, Lara MV, Andreo CS (2000) Induction of a C4-like mechanism of $\mathrm{CO}_{2}$ fixation in Egeria densa, a submersed aquatic species. Plant Physiol 123:1611-1621

Dai ZY, Ku MSB, Edwards GE (1993) C4 photosynthesis - the $\mathrm{CO}_{2}$ concentrating mechanism and photorespiration. Plant Physiol 103:83-90

DeGroote D, Kennedy RA (1977) Photosynthesis in Elodea canadensis Michx. Four carbon acid synthesis. Plant Physiol 59:1133-1135

DGA (Direccion General de Aguas de Chile) (1993) Diagnostico y Clasificacion de los cursos y cuerpos de agua segun objetivo de calidad: Cuenca Rio Valdivia. DGA, Ministerio de Obras Publicas, Santiago

Holaday AS, Bowes G (1980) C4 acid metabolism and dark $\mathrm{CO}_{2}$ fixation in a submersed aquatic macrophyte (Hydrilla verticillata). Plant Physiol 65:331-335 
Holaday AS, Salvucci ME, Bowes G (1983) Variable photosynthesis/photorespiration ratios in Hydrilla and other submersed aquatic macrophyte species. Can J Bot 61: 229-236

Gordon DM (1986) Variable $\left(\mathrm{HCO}_{3}\right)^{-}$affinity of Elodea canadensis Michaux in response to different $\left(\mathrm{HCO}_{3}\right)^{-}$and $\mathrm{CO}_{2}$ concentrations during growth. Oecologia 70:426-432

Leegood R (2002) $\mathrm{C}_{4}$ photosynthesis: principles of $\mathrm{CO}_{2}$ concentration and prospects for its introduction into $\mathrm{C}_{3}$ plants. J Exp Bot 53 (369):581-590

Long SP (1991) Modification of the response of photosynthetic productivity to rising temperature by atmospheric $\mathrm{CO}_{2}$ concentrations - has its importance been underestimated? Plant Cell Environ 14:729-739

Long SP (1999) Environmental responses. In: Sage RF, Monson RK (eds) C4 plant biology. Academic Press, San Diego, CA, p 215-249

Maberly SC, Madsen TV (2002) Freshwater angiosperm carbon concentrating mechanisms: processes and patterns. Funct Plant Biol 29:393-405

Magnin N, Reiskind JB, Bowes G (1996) Identification of PEPC isoforms from an aquatic monocot with inducible C4-type photosynthesis. Plant Physiol 111:S72

Magnin NC, Cooley BA, Reiskind JB, Bowes G (1997) Regulation and localization of key enzymes during the induction of Kranz-less, C4-type photosynthesis in Hydrilla verticillata. Plant Physiol 115:1681-1689

Moore BD, Ku MSB, Edwards GE (1987) C4 photosynthesis and light dependent accumulation of inorganic carbon in leaves of C3-C4 and C4 Flaveria species. Aust J Plant Physiol 14:657-688

Morton BA, Keeley JE (1990) C4 acid fixation in photosynthesis of the submerged aquatic Eleocharis acicularis (L.) R. \& S. Aquat Bot 36:379-388

Editorial responsibility: Brian Marcotte (Editor-in-Chief), Portland, Maine, USA
Parson T, Maita Y, Lalli C (1985) A manual of chemical and biological methods for seawater analysis. Pergamon Press, London

Prins HBA, Snel JFH, Zanstra PE, Helder RJ (1982) The mechanism of bicarbonate assimilation by the polar leaves of Potamogeton and Elodea. $\mathrm{CO}_{2}$ concentrations at the leaf surface. Plant Cell Environ 5:207-214

Reiskind JB, Madsen TV, Van Ginkel LC, Bowes G (1997) Evidence that inducible C4-type photosynthesis is a chloroplastic $\mathrm{CO}_{2}$-concentrating mechanism in Hydrilla, a submersed monocot. Plant Cell Environ 20:211-220

Salvucci ME, Bowes G (1983) Two mechanisms mediating the low photorespiratory state in submersed aquatic angiosperms. Plant Physiol 73:488-496

Sand-Jensen K, Spence DB, Maberly SC (1985) Occurrence and ecological importance of $(\mathrm{HCO} 3)^{-}$- use among aquatic higher plants. In: Lucas WJ, Berry JA (eds) Inorganic carbon uptake by aquatic photosynthetic organisms. Am Soc Plant Physiol, Rockville, MD, p 125-143

UACH (Universidad Austral de Chile) (2004) Primer Informe sobre 'Estudio sobre origen de mortalidades y disminucion de aves acuaticas en el santuario de la naturaleza Carlos Anwandter, en la Provincia de Valdivia'

UACH (Universidad Austral de Chile) (2005) Segundo Informe sobre 'Estudio sobre origen de mortalidades y disminucion de aves acuaticas en el santuario de la naturaleza Carlos Anwandter, en la Provincia de Valdivia'

WWF (World Wildlife Fund) (2005) Findings and recommendations report, WWF international assessment mission for the Carlos Anwandter nature sanctuary and CELCO pulp mill controversy in Valdivia, Chile. November 2005. Available at: http://assets.panda.org/ downloads/final_wwf_rio_cruces_report_english.pdf

Submitted: April 20, 2006; Accepted: May 2, 2006

Proofs received from author(s): June 15, 2006 